\title{
Mama I Don't Know
}

\author{
Maysam Abu Khreibeh
}

\begin{abstract}
This is a personal spoken word piece dedicated to my mother. The piece is an ode to both her sacrifices as a single mother as well as her journey as a Palestinian-Syrian refugee turned Canadian immigrant, in addition to my own feelings of displacement as a Muslim Palestinian-Syrian of colour dwelling in the lands of Turtle Island. The piece strives to make space for the pain that comes with being a child of diaspora; recognizing one's loss of cultural knowledge, familial connections, mother tongue, and connection to a land never seen. The piece explores how coming to know about one's roots and histories in relation to one's homeland, is a form of resistance to the erasure of a people, in this case - the Palestinian people. The feelings encapsulated within the piece, whether it be of rage, hope or desperation, are driven by the love one has for one's faith, land and people.
\end{abstract}

\section{Keywords}

Palestine, diaspora, family, culture, displacement, resistance 
Mama I wrote about you

I wrote about you in school

I made a comic book about you

I told my teachers

My classmates

With pride, I looked them dead in the eye

And said

Mama survived a mass bombing on her refugee camp when she was only 13 years old

We're almost 13

What in the world have we experienced?

\section{Honour mama}

Kiss mama's feet

Pray for her

For heaven is located under her feet

Her hard working feet

Feet that walked over broken bombshells

Toes that touched the dust of war

Heels split by the displacement of generations through ayta $^{1}$ and jido ${ }^{2}$

Syria and Palestine

Permanence in a temporary mokheyem ${ }^{3}$, a temporary place of refuge

1 The transliteration for the Arabic word meaning "grandmother".

2 The transliteration for the Arabic word meaning "grandfather".

3 The transliteration of the Arabic word meaning "refugee camp". 
But the site of another war

Extensions of the hate, the blood, the darkness shed from home

To the

foreign

place

of Canada

Mama tell me

please

Is it possible to build a true home in Canada - a home on native land?

Mama I spoke about you

I spoke about you in a poem

A poem I presented proudly in front of 1000 people

Mama it made my teacher cry

Cry because she felt my love for you

My honour for the name you gave me

The name you carried on your back

Like you carried me once

Balancing a single parent life

Mama you raised

Four hard headed kids on your back

All alone 
Our heads

Our heads were stubborn

Our heads harder than the helmets meant to protect IDF soldiers

From the resilience and strength of the rock

The weapon of the intifad ${ }^{4}$

Mama

Where did jido leave his rock?

Did he take it with him to the temporary place of refuge?

Or did he bury it under decades of blood in the once fertile land back home?

Mama I want to honour you

Mama I want to honour you so bad it hurts my heart knowing

that I can't teach my kids the mother tongue you sung to me on nights I was scared, the language that tayta used to wipe your tears, the words that you could use to share your own story

Mama it hurts that I have never seen it

You have never seen it

Mama it's in our blood

The olives

The lemons

4 The transliteration for the Arabic word meaning "uprising", referring to Palestinian grassroots resistance efforts. 
The dirt

The skies

It's in our blood but why, why can't I see it?

Time goes on

You're forgetting

We're losing

They're winning

This is what they wanted

Exile

Exile

Exile

Dirty Arabs

Go back to your country

But our land is your land

Your land is my land

No

No

No

Mama we're losing

I can't see

I can't taste 
All I ever wanted was to embrace

the olive tree

But they stripped it from its roots

Disembodied

Disembodied

Lost

Its taste

Its home

Its stability

Mama what's you without history?

Misplaced

I find myself retracing crumbs of knowledge in distant lands

Lands where the white man stole from the "Dirty Indian"

centuries before he stole from me

Mama I act because of you

Mama I do

I scramble, I ask questions - ashamed I don't know

But I don't blame you

For the loss

The grief I feel for something I never had 
Mama I act because of you

I move

I talk

I sing

I dance

I continue because of you

Mama I want to learn more for you

I want to share with you all that they stole from us

I want to dig into every archive,

every library,

every shelf,

every book,

into the depths of each page

Each word I want to analyze for every life they took,

and every step jido took,

and every tree that fell,

and every key that was stolen,

and every child that was taken in the midst of the night,

and every land succession,

and every bomb on the mokheyem,

and every $\operatorname{Athan}^{5}$ that was silenced,

5 The Arabic term for the call to prayer, recited by the muezzin during the five daily Islamic prayer times. 
Impossible silence.

I want each word that I unearth from the land to fly - fly and hit them hard

Hard like a bullet

Hard enough to shatter the rock solid wall of apartheid

that they have carried in their hearts and minds

to ignore our cries

As people,

people continue to die

Mama I breathe for you

For the essence of resilience

you transpire

in all the breaths you've shared with me

Story is our resistance

We are in a place of exile

Separated by generations

Separated by language

Separated by culture

But I swear on my life I will know

Every tale, every legend, every tear that was shed 
I will know, Mama

I will know 


\section{Author Biography}

Maysam is a Muslim settler with Palestinian and Syrian roots, dwelling on the unneeded lands of Turtle Island. She is a 4th year Global Development Studies and Concurrent Education major, with specializations in First Nations, Metis and Inuit studies, and History at Queen's University. Maysam is a part of Solidarity for Palestinian Human Rights (SPHR), and the Levana Gender Advocacy Centre (LGAC), in which she is committed to solidarity projects in her communities. In her poetry, she explores questions of home, intergenerational trauma, displacement and healing through her familial and ancestral connections. 